\title{
PENGARUH SKEMATA TERHADAP KOMPETENSI MEMBACA PEMAHAMAN BERBASIS TAKSONOMI RUDDELL
}

\author{
St. Nurbaya, Fathur Rahman, Rustono, Subyantoro \\ Program Pascasarjana Universitas Negeri Semarang \\ siti_nurbaya@uny.ac.id
}

\begin{abstract}
Abstrak
Penelitian ini bertujuan untuk mengetahui pengaruh skemata terhadap kompetensi membaca pemahaman berbasis taksonomi Ruddell dan kompetensi membaca apa saja yang sulit dicapai oleh mahasiswa. Sampel penelitian adalah mahasiswa PBSI FBS UNY semester enam. Pemilihan sampel menggunakan teknik random. Pengumpulan data menggunakan instrumen kompetensi membaca pemahaman berbentuk pilihan ganda dan instrumen skemata membaca berbentuk jawaban singkat. Uji reliabilitas untuk membaca pemahaman menggunakan program Quest (membaca pemahaman) dan Teori Respon Butir (Item Response Theory/IRT), sedangkan skemata yang berbentuk jawaban singkat dilakukan dengan uji Cronbach's Alpha. Analisis data menggunakan uji univariate analysis of covariance yang secara khusus hanya memperhatikan nilai F-hitung pengaruh skemata terhadap kompetensi membaca pemahaman berbasis Taksonomi Ruddell. Hasil penelitian menunjukkan bahwa skemata yang secara teoretis diasumsikan mempengaruhi kompetensi membaca ternyata dalam penelitian ini tidak memiliki pengaruh. Hal ini diketahui dari hasil analisis statistik dengan uji univariate analysis of covariance diperoleh F-hitung 0,560 dengan siqnifikansi 0,457>0,05, yang menunjukkan bahwa tidak ada pengaruh skemata terhadap kompetensi membaca berbasis Taksonomi Ruddell. Dalam taksonomi Ruddell kompetensi yang ditagihkan tidak bersifat parsial melainkan bersifat komperehensif antarkompetensi dan subkompetensi. Kompetensi membaca yang paling sulit dicapai adalah memprediksi (92,5\% menjawab salah), memahami ide-ide penjelas ( $82 \%$ menjawab salah), dan memecahkan masalah (60\% menjawab salah).
\end{abstract}

Kata kunci: skemata, membaca pemahaman, taksonomi Ruddell

\section{THE EFFECT OF SCHEMATA ON THE READING COMPREHENSION COMPETENCIES BASED ON RUDDELL'S TAXONOMY}

\begin{abstract}
This study aimed to find out the effect of schemata on the reading comprehension competencies based on Ruddell's and reading competencies that students find it difficult to acquire. The research sample comprised six semester students of PBSI FBS UNY. The sampling technique was the random sampling technique. The data were collected using a multiple choice reading comprehension test and a short answer reading schemata test.
\end{abstract}


The reliability of the reading comprehension test was assessed by the Quest program and Item Response Theory and that of the reading schemata test by Cronbach's Alpha. The data analysis used univariate analysis of covariance which specifically focused on the $\mathrm{F}_{\text {observed }}$ value for the reading comprehension competencies based on Ruddell's taxonomy. The results of the study showed that schemata, theoretically assumed to affect the reading competencies, had no effect on them. This was indicated by the results of the statistical analysis using univariate analysis of covariance test yielding $\mathrm{F}_{\text {observed }}=0.560$ with a significance value of $0.457>0.05$, showing that there was no effect of schemata on the reading competencies based on Ruddell's taxonomy. In Ruddell's taxonomy, the assessed competencies are not partial but they are composites of several competencies and subcompetencies. The most difficult reading competencies were predicting $(92.5 \%$ answering incorrectly), understanding explanatory ideas ( $82 \%$ answering incorrectly), and solving problems (60\% answering incorrectly).

Keywords: schemata, reading comprehension, Ruddell's taxonomy

\section{PENDAHULUAN}

Istilah skemata berawal dari teori skema, yang menggambarkan proses dimana pembelajar membandingkan latar belakang pengetahuan yang di miliki dengan informasi yang baru. Salah satu teori skemata yang mempengaruhi teori pembelajaran adalah teori yang dikemukakan oleh Piaget (dalam Ruddell, (2005:27). Piaget mendefinisikan skemata sebagai sebuah struktur kognitif intelektual individu berupa representasi persepsi, ide, dan aksi yang diasosiasikan, merupakan dasar pemikiran yang digunakan untuk beradaptasi dengan lingkungan dan mengaturnya menjadi sebuah modal untuk memahami pengetahuan baru, termasuk memahami pengetahuan baru yang disajikan penulis dalam teks yang dibaca.

Dipertegas oleh Piaget (dalam Hergenhahn, B.R and Olson Matthew H. 2002: 313) skemata di atas mengisyaratkan adanya faktor pendukung yang saling mengisi dan berproses. Kedua faktor tersebut adalah proses asimilasi dan proses akomodasi. Proses asimilasi adalah proses penyerapan konsep baru ke dalam struktur kognitif yang telah ada, pada proses asimilasi seseorang menggunakan struktur atau kemampuan yang ada untuk menanggapi masalah yang datang dari lingkungannya. Proses akomodasi adalah proses pembentukan skemata baru atau memodifikasi struktur kognitif yang telah ada supaya konsep-konsep baru dapat diserap. Skemata yang dimiliki seseorang baik melalui proses asimilasi maupun proses akomodasi dapat dimanfaatkan untuk memahamai teks sebelum peristiwa membaca dilakukan dengan cara memberikan analogi-analogi membuat perbandingan, menggunakan contoh-contoh, memanfaatkan gambargambar visual yang erat kaitannya dengan bacaan yang akan dibaca siswa (Indrawati, 1996).

Ada beberapa cara yang dapat dilakukan untuk menggunakan skemata dalam pembelajaran. Pemanfaatan skemata untuk 
meningkatkan pemahaman terhadap teks dapat dilakukan dengan membuat analogianalogi, membuat perbandingan serta menggunakan contoh, serta memanfaatkan gambar-gambar visual yang erat kaitannya dengan bacaan yang dapat dilakukan pada kegiatan prabaca, saat baca, dan pascabaca. Pemanfaatan skemata pada saat prabaca dilakukan untuk pembentukan pengetahuan awal, pengaktifan pengetahuan awal, dan pemfokusan perhatian siswa pada saat membaca.

Kegiatan pada saat membaca dimaksudkan untuk mengarahkan interaksi perhatian siswa dengan teks yang dibaca, sedangkan kegiatan pasca membaca dimaksudkan untuk memberikan pengulangan, balikan, dan rangsangan kognitif. Pangktifan pengetahuan awal pembaca terkait dengan isi teks dapat dilakukan dengan memusatkan perhatian, menggunakan kosakata kunci, serta pengaktifan pengetahuan awal yang dimiliki siswa sebagaimana dijelaskan Miller dan Perkins dalam (Pratiwi:2001). Pengaktifan pengatahuan awal dapat dilakukan misalnya dengan memberikan gambaran umum isi bacaan sebelum membaca atau memberikan analoginya. Semua tahapan pengguaan skemata yang diuraikan di atas bertujuan untuk memahami ringkasan atau gambaran isi teks yang akan dibaca berupa pengenalan ide utama yang dikemukakan penulis, peristiwa-peristiwa utama yang terdapat dalam teks sehingga memudahkan pemahaman isi teks yang dibaca.

Keterkaitan membaca dengan skemata terletak pada proses kognitif dalam pemaknaan konsep yang terdapat dalam teks dengan memanfaatkan pengetahuan atau latar belakang pengetahuan tentang teks yang dibaca, baik berupa pengetahu- an kebahasaan, kosakata, frase maupun unsur bahasa lainnya termasuk tanda baca. Piaget (dalam Dworetzky, 1990:243) menjelaskan bahwa mengembangkan skemata bertujuan untuk memperthanan masalah penting yang telah diketahuinya dengan proses berpikir. Pernyataan Piaget tersebut tetap melibatkan proses asimilasi dan akomodasi, dengan demikian skemata dalam membaca adalah proses komunikasi interaktif yang melibatkan latar belakang pengetahuan tentang bahasa, kosakata, maupun organisasi gagasan, struktur teks yang dipengaruhi oleh proses asimilasi dan proses akomodasi guna memahami teks yang dibaca.

Skemata diasumsikan akan membantu pembaca memahami teks yang akan dibaca. Oleh sebab itu, dapat dikatakan bahwa skemata dan membaca merupakan dua hal yang saling berkaitan. Keterkaitan antara skemata dan membaca terletak pada upaya pemahaman terhadap informasi yang terdapat dalam teks yang dibaca melalui sebuah proses interaksi kognitif dalam diri pembaca.

Proses kognitif tersebut diperlukan untuk memahami informasi yang dibaca dengan memanfaatkan pengetahuan lama atau pengetahuan lain yang pernah ada terkait isi teks. Oleh sebab itu, kompetensi membaca setiap orang akan berbeda beda sesuai dengan skemata yang dimilikinya. Hal ini terjadi karena pembaca akan memanfaatkan skemata yang dimilikinya untuk melakukan asosiasi tentang "sesuatu" yang dibaca dengan membayangkan kembali makna dari yang dibaca sesuai dengan kata, frasa, atau kalimat yang dibaca. Dapat juga dikatakan bahwa pembaca akan memahami isi teks yang dibaca jika informasi baru yang terdapat dalam teks cocok atau 
ada relevansinya dengan skemata yang dimilikinya.

Rumelhart dalam tulisannya yang berjudul Scemata Theory and The Desaign of Content-Area Texbook (1980) membagi skemata dalam lima jenis, yakni skemata ideologi, skemata sosial, skemata lingusitik, skemata isi, dan skemata formal. Penggolongan jenis skemata antara Carrell dan Eisterhold dan Rumelhart dilakukan berdasarkan pada apa yang diketahui oleh seseorang dan fungsi skemata dalam proses pemahaman informasi, karena dua jenis skemata yakni, skemata idiologi dan skemata sosial tidak termasuk dalam cakupan pembahasan pembelajaran ilmu bahasa khususnya pembahasan yang berkaitan dengan proses pemahaman isi bacaan, dan 3 jenis lainnya yakni skemata formal, skemata isi, dan skemata linguistik yang ada kaitannya dengan pembelajaran bahasa terutama dalam kaitannya dengan membaca.

Skemata idiologi adalah struktur pengetahuan yang dimiliki seseorang terkait dengan pemahamannya tentang idiologi atau faham tentang suatu nilai yang terdapat dan berkembang dalam masyarakat. Skemata sosial adalah pengetahuan awal manusia terkait dengan struktur sosial kemasyarakatan yang dapat membantu manusia memahami kehidupan sosial kemasyakatan Rumelhart(1980).Skemata formal adalah kepemilikan pengetahuan seseorang terkait dengan struktur tatanan teks baik berupa struktur retorik teks, gente teks, maupun sifat umum teks.

Skemata linguistik adalah kepemilikan pengetahuan kebahasaan manusia berupa kosakata, frase, kalimat yang kesemuanya digunakan untuk melakukan decoding guna memahami teks yang dibaca, sedangkan skemata isi atau skemata konten mengacu pada pengetahuan awal pembaca terkait dengan isi teks yang dibaca. Sebagai sebuah proses berpikir, skemata berfungsi pada saat pembaca mengintegrasikan informasi baru dan membiarkan informasi baru masuk menjadi bagian dari pengetahuan yang telah ada. Skemata ini mencakup konsepkonsep yang meliputi objek, situasi, urutan peristiwa, tindakan, dan urutan tindakan

Bartlett (1932) seperti dikutip oleh Li Xiao-Hui (2006) dalam artikelnya yang berjudul Analysis of Schema Theory and its Influence on Reading mendefinisikan skemata adalah "an active organization of past reactions of past experiences, which must always be supposed to be operation in any well-adapted organic response" Pengertian ini mengacu pada pemanfaatan dan pengaturan pengetahuan masa lalu yang selalu digunakan untuk merespon pengetahuan baru. Respon yang dimaksud adalah upaya untuk memahami pengetahuan baru, yang baru dilihat, baru diketahui atau yang baru dibaca.

Pengertian yang hampir sama dikemukakan oleh Rumelhart (1977) yang mendefinisikan skemata sebagai cara kerja unitunit pengetahuan lama yang dimiliki seseorang dan digunakan untuk memahami pengetahuan baru. Dipertegas oleh Rumelhart (1980) seperti dikutip dari Jose Luiz Meurer (2000 : 168) bahwa skemata adalah "pengalaman dan pengetahuan yang terorganisir dalam pikiran dengan variabelvariabelnya (subkomponen) untuk memahami hal yang sama dengan pengetahuan yang baru dibaca atau diketahui."

Sementara Widdowson (1983) mendefinisikan skemata adalah "cognitive constructs which allow for the organization of information in a long-term memory". Hal 
yang sama dikemukakan oleh Anderson (dalam Winograd, 1979) skemata adalah "structure"containing slots, or place holders, for each of the component pieces of information subsumed under the more general idea, or structure. Pengertian-pengerian tersebut di atas dapat dipahami sebagai sebuah proses pemahaman terhadap pengetahuan baru dengan memanfaatkan stuktur atau konstruksi kognitif yang memungkinkan seseorang melakukan pengorganisasi informasi dalam memori jangka panjang. Banyak faktor yang mempengaruhi konstruksi kognitif seseorang, salah satu faktor adalah aktivitas membaca.

Lewat kegiatan membaca seseorang akan memperoleh banyak informasi. Informasi-informasi tersebut akan disimpan dalam memori yang sewaktu-waktu dapat digunakan untuk mempermudah memahami informasi lain yang berhubungan dengan informasi baru yang dibaca. Hal ini menunjukkan bahwa kegiatan membaca dan skemata memiliki hubungan timbal balik atau bahwa membaca dan skemata merupakan dua hal yang saling berkaitan erat karena untuk dapat memahami informasi dengan baik, pembaca perlu menggunakan skemata (konstruk kognitif) yang dimiliki yang terkait dengan teks yang dibaca. Skemata dapat juga berfungsi sebagai modal utama pemaknaan isi teks. Oleh sebab itu, dapat diasumsikan bahwa skemata memiliki konstribusi atau pengaruh terhadap kompetensi membaca yang dipengaruhi oleh faktor yang saling mendukung seperti diungkapkan oleh Piaget (dalam Hergenhahn, B.R and Olson Matthew H.2002: 313).

Berkaitan dengan skemata yang dikemukakan oleh Piaget di atas mengisyaratkan bahwa dalam skemata terdapat faktor pendukung yang saling mengisi dan berproses. Kedua faktor tersebut adalah proses asimilasi dan proses akomodasi. Proses asimilasi adalah proses penyerapan konsep baru ke dalam struktur kognitif yang telah ada, pada proses asimilasi seseorang menggunakan struktur atau kemampuan yang ada untuk menanggapi masalah yang datang dari lingkungannya. Proses akomodasi adalah proses pembentukan skemata baru atau memodifikasi struktur kognitif yang telah ada supaya konsep-konsep baru dapat diserap.

Skemata yang dimiliki seseorang baik melalui proses asimilasi maupun proses akomodasi dapat dimanfaatkan untuk memahamai teks sebelum peristiwa membaca dilakukan dengan cara memberikan analogi-analogi membuat perbandingan, menggunakan contoh-contoh, memanfaatkan gambar-gambar visual yang erat kaitannya dengan bacaan yang akan dibaca siswa (Indrawati, 1996).

Asumsi dasar relevansi teori skema dengan aktivitas membaca adalah bahwa "pemahaman" terhadap teks yang dibaca tidak hanya karena pembaca memahami apa yang disampaikan oleh penulis secara tersurat melainkan juga pemahaman yang tersirat yang dipengaruhi oleh pengetahuan lain atau pengetahuan awal yang dimiliki pembaca terkait isi teks yang dibaca, atau dapat dikatakan bahwa pemahaman terhadap teks tidaklah sepenuhnya karena pembaca memahami secara tektual apa yang tertuang dalam bacaan melainkan juga karena pembaca memiliki pengetahuan awal tentang apa yang dibaca.

Teks yang dibaca hanya memberikan petunjuk kepada pembaca untuk menyusun pengertian/pemahaman berdasarkan pengetahuan yang telah dimiliki sebelum- 
nya. Berdasarkan skema yang dimilikinya pembaca berupaya memahami teks yang dibacanya. Pernyataan teoretis tersebut di atas, menunjukkan bahwa skemata memiliki relevansi dengan membaca pemahaman. Meski demikian belum ada satupun dari pernyataan tentang relevansi skemata dengan kompetensi membaca yang melihat relevansinya dengan taksonomi Ruddell.

Taksonomi Ruddell merupakan revisi dari taxonomi Barret dalam "The Taxonomi of the Cognitive and Affective of Reading Comprehension" (Harris, Myers: 2004). Semula taksonomi Barret berisi 5 kompetensi tetapi, oleh Ruddell direvisi menjadi taksonomi yang simpel tetapi tetap memuat kelima kompetensi membaca yang dikemukakan Barret.

Taksonomi Barret diilhami oleh taksonomi Bloom, tetapi pengkategorian dalam taksonomi Barret disesuaikan dengan kegiatan dan proses kognitif membaca, sehingga terdapat lima tingkatan kompetensi membaca yang dapat diukur. Lima kompetensi membaca seperti dikemukakan Barret tersebut di atas terlalu rumit untuk diaktualisasikan dalam pengukuran membaca (Listyani 2012:42), sehingga Ruddell menyederhanakannya menjadi tiga kompetensi yang mencakup, pemahaman faktual, pemahaman interpretatif, dan pemahaman aplikatif (Ruddell, 1978).

Masing-masing tingkatan pemahaman tersebut berisi kompetensi-kompetensi tertentu. Kompetensi-kompetensi tersebut adalah: ide penjelas, urutan, sebab akibat, ide pokok, memprediksi, menilai, dan pemecahan masalah. Penjelasan tentang klasifikasi kompetensi tersebut beserta subkompetensi membaca pemahaman diuraikan Ruddell seperti tertera pada tabel berikut.

Tabel 1 Taksonomi Membaca Rudell

\begin{tabular}{|c|c|c|c|}
\hline \multirow{2}{*}{ Kompetensi kompetensi } & \multicolumn{3}{|c|}{ Tingkat Pemahaman } \\
\hline & Faktual & Interpretatif & Aplikatif \\
\hline \multicolumn{4}{|l|}{ 1. Ide-ide Penjelas } \\
\hline a. Mengidentifikasi & $\sqrt{ }$ & $\sqrt{ }$ & $\sqrt{ }$ \\
\hline b. Membandingkan & $\sqrt{ }$ & $\sqrt{ }$ & $\sqrt{ }$ \\
\hline c. Menggolongkan & & $\sqrt{ }$ & $\sqrt{ }$ \\
\hline 2. Urutan & $\sqrt{ }$ & $\sqrt{ }$ & $\sqrt{ }$ \\
\hline 3. Sebab dan Akibat & $\sqrt{ }$ & $\sqrt{ }$ & $\sqrt{ }$ \\
\hline 4. Ide Pokok & $\sqrt{ }$ & $\sqrt{ }$ & $\sqrt{ }$ \\
\hline 5. Memprediksi & & $\sqrt{ }$ & $\sqrt{ }$ \\
\hline 6. Menilai & $\sqrt{ }$ & $\sqrt{ }$ & $\sqrt{ }$ \\
\hline a. Penilaian Pribadi & $\sqrt{ }$ & $\sqrt{ }$ & $\sqrt{ }$ \\
\hline b. Identifikasi & & $\sqrt{ }$ & $\sqrt{ }$ \\
\hline \multicolumn{4}{|l|}{ Perwatakan } \\
\hline \multicolumn{4}{|l|}{ c. Identifikasi Motif } \\
\hline \multicolumn{4}{|l|}{ Pengarang } \\
\hline 7. Pemecahan Masalah & & & $\sqrt{ }$ \\
\hline
\end{tabular}

Sumber: Ruddell, Robert B. (1978) Developing Comprehension Abilites : Implication from Research for an Instructional Framework. 
Berdasarkan uraian di atas, penelitian ini bertujuan mengatahui pengaruh skemata terhadap kompetensi membaca berbasis taksonomi Ruddell, dan kompetensi mana saja yang paling sulit dikuasai oleh mahasiswa?

\section{METODE}

Penelitian ini adalah jenis penelitian kuantitatif. Jumlah sampel penelitian 35 orang mahasiswa. Sampel penelitian diperoleh dengan teknik random sampling. Sumber data ada dua yakni (1) data skemata mahasiswa terkait dengan delapan teks yang dibaca, (2) data kompetensi membaca mahasiswa berbasis taksonomi Ruddell. Instrument pengumpul data yang digunakan adalah instrument kompetensi membaca pemahaman berjumlah 40 item berbentuk pilihan ganda, dan instrument kedua adalah untuk menjaring data skemata berbentuk soal uraian dengan jawaban singkat.

Uji reliabilitas instrument kompetensi membaca menggunakan program Ques yang menggunakan asumsi Teori Respon Butir (Item Response Theory/IRT), sedangkan uji reliabilitas instrumen skemata yang berbentuk soal uraian dengan jawaban singkat dilakukan dengan uji Croncbah Alfa. Analisis data dilakukan dengan statitistik parametrik dengan uji Univariate Analysis of Co Variance yang secara khusus hanya memperhatikan nilai $\mathrm{F}$ hitung pengaruh skemata terhadap kompetensi membaca pemahaman berbasis. Sebelum analisis data dilakukan terlebih dahulu dilakukn uji persyaratan analisis yakni uji normalitas dan homogenitas data. Uji normalitas dilakukan dengan uji Kolmogorof-Smirnov Goodness of Fit, sedang uji homogenitas data menggunakan uji Levene's Test of Equal- ity. Berdasarkan hasil uji Kolmogorof-Smirnov Goodness of Fit data dalam kompetensi membaca pemahaman dalam penelitian ini normal hal ini ditunjukkan oleh nilai $p$ value $0,200>0,05$ sehingga resiudal berdistribusi normal, demikian juga dengan hasil uji homogentitas dieroleh nilai $\mathrm{F}: 0,808$ pada df $1: 1$ dan df2: 68 nilai sig: 0,372. Karena nilai sig ( $p$ value) $0,372>0,05$ maka data kompetensi membaca homogen.

\section{HASIL DAN PEMBAHASAN \\ Pengaruh Skemata terhadap Kompetensi Membaca Berbasisi Taksonomi Ruddell}

Hasil uji pengaruh antara skemata dan membaca pemahaman berbasis taksonomi Ruddell ditunjukkan dengan $F$ hitung 0,560 dengan siqnifikan 0,457>0,05. Hal ini menunjukkan skemata tidak berpengaruh terhadap kompetensi membaca berbasis taksonomi Ruddell.

Berdasarkan nilai pengaruh yang tidak signifikan tersebut memperkuat teori Piaget (dalam Hergenhahn, B.R and Olson Matthew H.2002: 313). Menurut Piaget skemata baik yang dimiliki seseorang mengisyaratkan adanya faktor pendukung yang saling mengisi dan berproses. Kedua faktor tersebut adalah proses asimilasi dan proses akomodasi. Dalam skemata asimilasi dan proses akomodasi yang disebut funcitional invarians oleh (Hergenhahn, B.R and Olson Matthew H.2002: 315) terjadi pada semua level perkembangan intelektual, termasuk pada mahasiswa. Proses asimilasi adalah proses penyerapan konsep baru ke dalam struktur kognitif yang telah ada, pada proses asimilasi seseorang menggunakan struktur pengatahuan lama yang dimilikinya atau kompetensi yang dimilikinya untuk menanggapi masalah yang datang dari lingkungannya. 
Mahasiswa yang telah membaca beberapa teks yang berkaitan dengan teks yang akan diujikan telah diasumsikan telah memiliki skemata tentang isi teks tersebut, dan pada saat membaca teks mahasiswa sesungguhnya tidak hanya melibatkan skemata yang dimilikinya melainkan ada keterlibatan menggunakan yang ada kaitannya dengan skemata tentang teks, mahasiswa mampu mengerjakan soal-soal membaca berbasis taksonomi Raddell secara keseluruhan atau secara umum dengan baik. Membaca teks-teks baru yang ada kaitannya dengan teks tersebut secara umum menunjukkan adanya proses adanya keterlibatan intelektual akomodasi. Proses akomodasi merupakan proses pembentukan skemata baru atau memodifikasi struktur kognitif yang telah ada, supaya konsepkonsep baru dapat diserap dari teks yang dibaca. Selain proses asimilasi dan akomodasi dalam pemanfaatan skemata proses asimilasi memungkinkan pembaca merespon isi teks sesuai dengan pengetahuan yang dimiliki sebelumnya. Artinya dalam diri pembaca ada aspek unik yang mempengaruhi proses asimilasi yang terjadi. Jika aspek unik dalam diri pembaca tidak terjadi ketika proses membaca maka, pembaca akan mengalami kesulitan untuk memahami teks yang dibaca, atau oleh Piaget dikenalkan dengan istilah ketidakseimbangan kognitif.

Oleh sebab itu, skemata yang dimiliki seseorang pembaca baik melalui proses asimilasi maupun proses akomodasi dapat dimanfaatkan untuk memahamai teks sebelum peristiwa membaca dilakukan. Pembaca terlebih dahulu akan melakukan analogi-analogi, membuat perbandingan, menggunakan contoh-contoh, memanfaatkan gambar-gambar visual yang erat kaitan- nya dengan bacaan yang akan dibaca siswa seperti dijelaskan oleh (Indrawati, 1996). Ini sejalan dengan apa yang dikatakan oleh Bartlett (1932) yang dikutip oleh Li XiaoHui (2006) yang mengatakan bahwa pemanfaatan dan pengaturan pengetahuan masa lalu selalu digunakan untuk merespon pengetahuan baru.

Respon yang dimaksud adalah upaya untuk memahami pengetahuan baru, yang baru dilihat, baru diketahui atau yang baru dibaca, sehingga temuan penelitian tentang pengaruh skemata dengan kompetensi membaca berbasis taksonomi Ruddell secara umum menunjukkan bahwa antara skemata dengan kompetensi membaca saling memberikan konstribusi untuk memahami teks. Dalam hal ini skemata digunakan untuk menyusun, memaknai dan menafsirkan pengalaman masa lampau tentang isi teks, atau boleh dikatakan bahwa skemata dianggap sebagai deterministis, menjadikan orang yang memilikinya cenderung untuk menafsirkan pengalamannya dengan cara yang tetap atau cara yang sama.

Dalam berbagai penelitian tentang skemata dan kompetensi membaca, skemata berpengaruh terhadap kompetensi membaca, skemata selalu menunjuk pada sebuah situasi yang timbul dari sejumlah praanggapan yang dianggap benar sebagai dasar merumuskan kesimpulan, dasar pemikiran, argumentasi, bahkan skemata dalam hal ini oleh pembaca dijadikan asumsi untuk menganalisis sejumlah informasi yang tertangkap ketika pembaca berinteraksi dengan teks seperti pada temuan penelitian Zamzani (2015). Dalam penelitian ini, skemata seperti di atas bersifat paradok, karena dalam konteks penelitian ini tidak menghasilkan hasil yang 
sama, hal ini mungkin saja terjadi pada peneliti-peneliti tentang pengaruh skemata terhadap kompetensi membaca karena kompetensi membaca yang diukur tidak spesifik mengacu pada taksonomi tertentu, terutama taksonomi Ruddell.

\section{Kompetensi Membaca Berbasis Taksonomi Ruddell yang Paling Rendah Dikuasai Mahasiswa}

Dalam taksonomi Ruddell kompetensi yang ditagihkan tidak bersifat parsial melainkan bersifat komperehensif antar kompetensi dan subkompetensi. Rendahnya prosentase kompetensi menjawab kompetensi memprediksi dengan 92,5\%, diikuti oleh kompetensi memahami ide-ide penjelas sebanyak $82 \%$, serta kompetensi memecahkan masalah sebesar $60 \%$ atau menunjukkan perbedaan penelitian ini dengan penelitian lainnya yang mencoba menelisik pengaruh skemata dengan kompetensi membaca. Hasil penelitian lain (Zamzani, 2015) menunjukkan bahwa pengaruh skemata terhadap kompetensi membaca lebih nyata memperlihatkan pengaruhnya bila pembaca memiliki skemata 1) konten terkait teks, 2) skema formal kesadaran akan struktur teks, dan 3) skema bahasa yakni pengetahuan tentang kosa kata danhubungan kata-kata dalam teks.

Tingginya angka kesulitan menjawab dengan soal kompetensi membaca berbasis taksonomi Ruddell pada kompetensi memprediksi, kompetensi memahami ide-ide penjelas dan kompetensi memecahkan masalah menunjukkan bahwa walau secara umum skemata berpengaruh terhadap kompetensi membaca tetapi jika ditelisik berdasarkan tiap-tiap kompetensi dan subkompetensi menunjukkan hasil yang tidak sama. Perbedaan hasil penelitian ini dengan penelitian lain tentang pengaruh skemata dengan kompetensi membaca mungkin juga disebabkan kompetensi membaca yang diujikan tidak menggunakan tagihan kompetensi membaca berbasis taksonomi tertentu, termasuk taksonomi Ruddell.

Hasil penelitian ini bukan satu-satunya penelitian tentang tidak berpengaruh skemata terhadap kompetensi membaca pemahaman. Penelitian dengan temuan yang sama dilakukan oleh Al-Salmi yang berjudul Scemata (Backraund Knowledge) and Reading Comprehension for EFL Studens (2011). Hasil penelitiannya adalah pemanfaatan skemata dalam pembelajaran bahasa Inggris tidak menghasilkan perbaikan dan pemahaman terhadap teks yang dibaca, terutama dalam memahami hal-hal yang bersifat spesifik atau hal-hal yang kaitan dengan rincian-rincaian yang diungkapkan oleh penulis dalam teks, hanya saja Al-Salmi tidak menjelaskan secara rinci tentang temuannya yang secara spesifik atau rincian-rincian tersebut berkaitan dengan aspek apa saja, sementara dalam penelitian ini aspek yang dilacak sangat jelas sesuai dengan kompetensi dan subkompetensi membaca berbasis Taksonomi Ruddell.

\section{SIMPULAN}

Skemata yang secara teoretis diasumsikan mempengaruhi kompetensi membaca, ternyata dalam penelitian ini tidak ada pengaruhnya. Hal ini diketahui dari hasil analisis statistik dengan uji Univariate Analysis of Co Variance diperoleh $\mathrm{F}$ hitung 0,560 dengan siqnifikan 0,457>0,05 yang menunjukkan bahwa tidak ada pengaruh skemata terhadap kompetensi membaca berbasis Taksonomi Ruddell.

Dalam taksonomi Ruddell kompetensi 
yang ditagihkan tidak bersifat parsial melainkan bersifat komperehensif antarkompetensi dan subkompetensi. Kompetensi membaca berbasis taksonomi Ruddell yang paling sulit dijawab adalah kompetensi memprediksi dengan 92,5\% mahasiswa menjawab salah, atau mahasiswa yang menjawab dengan benar kompetensi ini hanya $7,5 \%$. diikuti oleh kompetensi memahami ide-ide penjelas sebanyak $82 \%$ menjawab salah atau hanya $18 \%$ mahasiswa yang menjawab benar, serta serta kompetensi memecahkan masalah sebesar $60 \%$ menjawab salah atau hanya $40 \%$ mahasiswa yang menjawab dengan benar. Hal ini menunjukkan perbedaan penelitian ini dengan penelitian lainnya yang mencoba menelisik pengaruh skemata dengan kompetensi membaca berbasis taksonomi Ruddell.

\section{UCAPAN TERIMA KASIH}

Melalui jurnal ini penulis sampaikan ucapan terima kasih kepada beberapa pihak yang telah membantu pelaksanaan penelitian disertasi ini. Pertama ucapan terima kasih penulis sampaikan kepada ketiga promotor penulis, Prof. Dr. Fathur Rahman, M.Hum, Prof. Dr. Rustono, M.Hum, dan Prof. Dr. Subyantoro, M.Hum. yang telah membimbing penulis dalam penyelesaian penulisan disertasi. Kedua ucapan terima kasih penulis sampaikan kepada Rektor Universitas Negeri Yogyakarta atas bantuan penulisan disertasi yang telah diberikan. Ketiga ucapan terima kasih penulis sampaikan secara khusus kepada Dewan Redaksi Jurnal Litera Ketua dan Sekertaris yang telah bersedia mereviu tulisan ini menjadi lebih baik. Keempat ucapan terima kasih penulis sampaikan kepada mahasiswa PBSI angkatan 2014 yang telah bekerjasama menjadi sampel penelitian ini. Semoga segala Allah membalas segala kebaikan dan kemudahan yang diberikan kepada penulis. Aamiin.

\section{DAFTAR PUSTAKA}

Al Salmi, Mahfood. 2011. Scemata (Backgraund Knowledge) and Reading Comprehension For EFL Studend. Research Journal Specific Education Faculty of Specific Education Mansoura University. http://www1.mans. edu.eg/facse/arabic/magazine/ no_22/21.pdf. Diakses 6 April 2016.

Dworezky, J.P. 1990. Intrudution to Child Development, New York: West, Publishing Company.

Harris,B.L,\& Myers,S. S. 2004. Teachers Guide Manual for Formualting Reading Comprehension Questions. The New Horizons for Primary Schools (NPH) is a seven-year, join initiative of the Goverment of Jamaica (GOJ) and the United Sates Agency for International Development (USAID).

Hergenhahn,B.R and Olson Matthew H. 2002. Teori of Learning. (terjemahan) Kencana Prenada Media Group. Jakarta.

Indrawati, Sri, dkk 2008. Peningkatan Keterampilan Membaca Melalui Pemetaan Skemata isi dan Struktur Teks. Jurnal Forum Pendidikan. Vol, 28. Nomor 1, September. Universitas Sriwijaya Pelembang.

Li Xiao-Hui, Wu Jun, Wang Wei-Hua. 2006. Analysis of Schema Theory and Its Influence on Reading School of Foreign Languages, Wuhan University Of Technolog, Wuhan430070, China. 2 April 2016.

Prayitni, T. Endah. 2011. Pengembangan Bahan Ajar Membaca Kritis Berbasis 
Intervensi Responsif dengan Multimedia. Disertasi. Malang: Program Pascasarjana. Universitas Negeri Malang. Pelenkahu,Noldy. 2006. Hubungan antara Pengetahuan Awal dan Penguasaan Kosakata terhadap Keterampilan Membaca Pemahaman. Artikel. STIE Setia Budi Jakarta. Jurnal Pendidikan dan Kebudayaan No.063, Tahun ke-12

Ruddell, Robert B. 1978. Developing Comprehension Abilites: Implication from Research for an Instructional Framework. http:/scholarspace.manoa.hawaii.edu.

Ruddell,R. Martha. 2005. Teching Content Reading and Writing. Four Edition.
USA: Hermitage Publishing Sevices. Rumelhart 1980. Scemata Theory and The Desaign of Content-Area Texbook. http:/ scholarspace.manoa.hawaii.edu.

Widdowson, H.G. 1995. Learning Purpose and Language Oxford: Oxford University Press.

Zamzani \& Suhardi. 2005. "Strategi Pendayagunaan Skemata Mahasiswa dalam Pembelajaran Membaca: Upaya Peningkatan Efektivitas Membaca". Litera, Volume 4, Nomor 2, Juli 2005. Yogyakarta: Fakultas Bahasa dan Seni, Universitas Negeri Yogyakarta. 